University of Nebraska - Lincoln

DigitalCommons@University of Nebraska - Lincoln

2006

\title{
Invasive Insect Abundance Varies across the Biogeographic Distribution of a Native Host Plant
}

Tatyana A. Rand

University of Nebraska - Lincoln, tatyana.rand@ars.usda.gov

Svata M. Louda

University of Nebraska - Lincoln, slouda1@unl.edu

Follow this and additional works at: https://digitalcommons.unl.edu/bioscilouda

Part of the Ecology and Evolutionary Biology Commons

Rand, Tatyana A. and Louda, Svata M., "Invasive Insect Abundance Varies across the Biogeographic Distribution of a Native Host Plant" (2006). Svata M. Louda Publications. 6.

https://digitalcommons.unl.edu/bioscilouda/6

This Article is brought to you for free and open access by the Papers in the Biological Sciences at DigitalCommons@University of Nebraska - Lincoln. It has been accepted for inclusion in Svata M. Louda Publications by an authorized administrator of DigitalCommons@University of Nebraska - Lincoln. 


\title{
INVASIVE INSECT ABUNDANCE VARIES ACROSS THE BIOGEOGRAPHIC DISTRIBUTION OF A NATIVE HOST PLANT
}

\author{
Tatyana A. Rand ${ }^{1}$ and Svata M. Louda \\ School of Biological Sciences, University of Nebraska, Lincoln Nebraska 68588-0118 USA
}

\begin{abstract}
Studies of biogeographic variation in species abundances are fundamental to understanding and predicting the impacts of invasive exotic species. We quantified the abundance of the introduced and now invasive biocontrol weevil, Rhinocyllus conicus, on a newly adopted native host plant, Cirsium canescens (Platte thistle), across the plant's distributional range. We used regression and structural equation analyses to examine variation in weevil abundance at $92-108$ sites over three years in relation to variation in abiotic and biotic parameters hypothesized to be important in insect or plant dynamics and distribution. We found that $R$. conicus now occurs throughout the majority of the range of $C$. canescens, even in the center of the native plant's distribution where its coevolved, targeted weed host (Carduus nutans, musk thistle) is absent. In fact, weevil densities were greater in the center of the native plant's distribution in the Sand Hills formation than in peripheral sand patches closer to areas where the targeted exotic thistle is common. None of the macroclimatic variables examined were consistent predictors of the large-scale variation in weevil abundance on C. canescens. In addition to biogeographic position, the only other consistent predictor of weevil densities across sites was the number of flower heads per $C$. canescens plant. These results exclude the "spillover" hypothesis to explain nontarget feeding on this newly adopted native host species. Instead, the results are consistent with the alternative hypothesis that exotic weevil abundance on $C$. canescens is related to the local availability of native floral resources. Because $C$. canescens densities have declined with increases in $R$. conicus at sites central in the plant's distribution, these results suggest that isolated, peripheral populations of C. canescens are likely to be critical for persistence of Platte thistle. More generally, this study suggests that the persistence of a native species that is impacted by an exotic natural enemy may require preservation of populations in habitats outside the optimal portion of the native species' distribution.
\end{abstract}

Key words: biogeography; biological control; Cirsium canescens; herbivory; insect invasion; insectplant interactions; nontarget effects; plant conservation; Rhinocyllus conicus; spillover predation; weed control.

\section{INTRODUCTION}

Invasive exotic species are a leading threat to native species and ecosystems (Vitousek et al. 1996, Ewel et al. 1999, Pimentel et al. 2000). Biological control is proposed as an ecological solution for the management of invasive species (Debach and Rosen 1991, Van Driesche and Bellows 1996), including, specifically, in nature reserves and natural areas (Malecki and Blossey 1994, Hoddle 2004). However, the fact that classical biological control itself involves the purposeful introduction of nonnative natural enemies, such as insects, into new environments has raised concern (e.g., Howarth 1991, Louda et al. 1997, Louda and Stiling 2004). Understanding the factors influencing the distribution and abundance and, thus, potential impact of invasive species is generally important in informing conservation

Manuscript received 28 January 2005; revised 20 September 2005; accepted 11 October 2005. Corresponding Editor: J. A. Logan.

${ }^{1}$ Present address: Agroecology, University of Goettingen, Waldweg 26, 37073 Goettingen, Germany.

E-mail: tatyana_rand@hotmail.com strategies, including when an introduced biological control species is found to use nontargeted native plants in the new environment. Such data should be particularly useful in the continued development of risk assessment protocols for biological control efforts. Furthermore, few studies have quantitatively assessed factors potentially influencing invasive species dynamics and interactions across larger spatial scales (Higgins and Richardson 1996). In particular, we found no published examination of the larger scale pattern in nontarget attack by any of the biocontrol insects reported to date to feed on newly adopted native host plant species. In this study we quantified spatial patterns and examined potential predictors of variation in distribution and abundance of an introduced Eurasian inflorescence feeding weevil, Rhinocyllus conicus Frölich, on its newly acquired host plant Platte thistle, Cirsium canescens Nutt., across the center of the native plant's distributional range in sand prairie in the upper Great Plains, USA.

The weevil was introduced into North America in 1968 to limit the exotic musk (or nodding) thistle, 

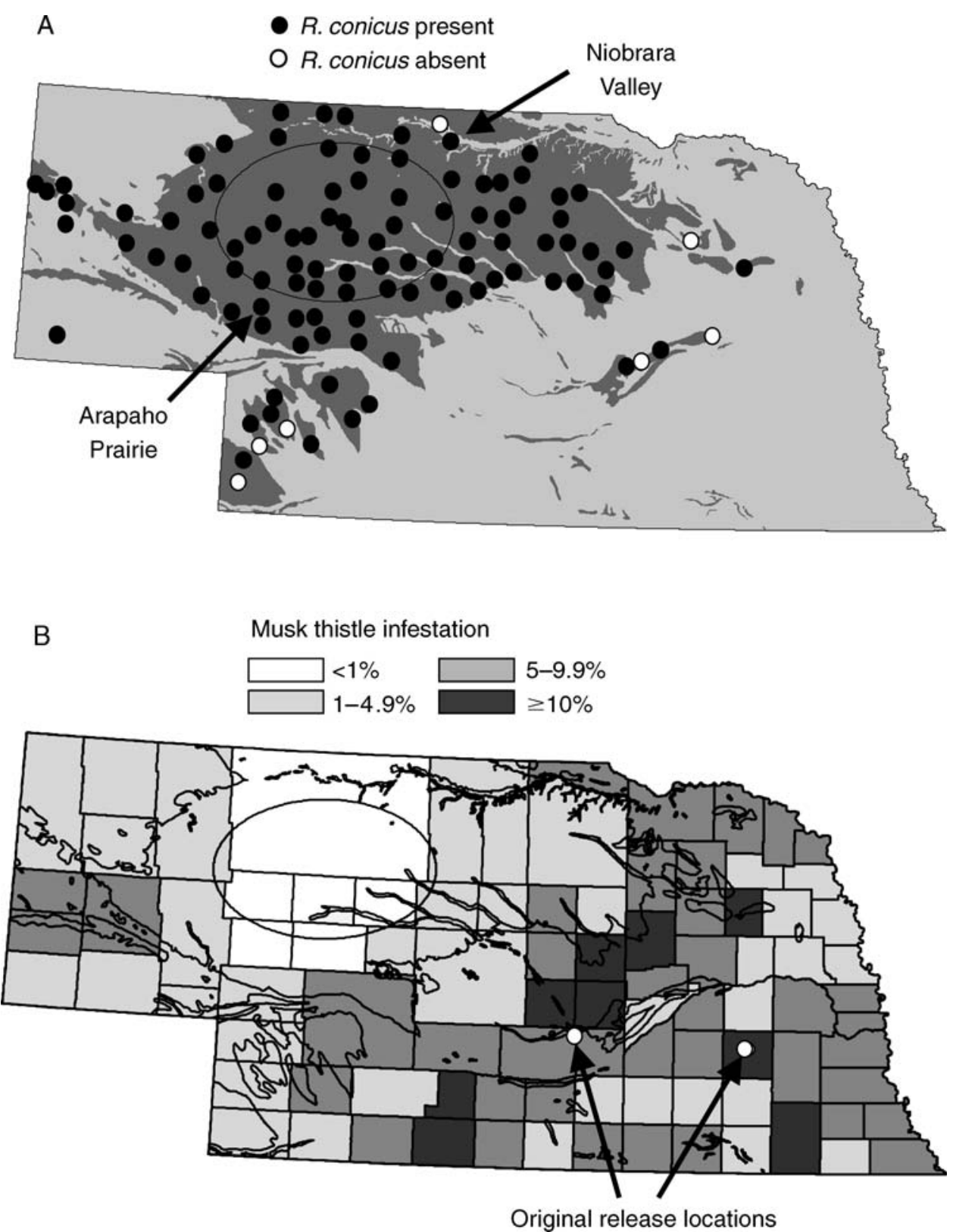

FIG. 1. (A) Map of sampling locations for an invasive weeveil, Rhinocyllus conicus, on its adopted native host plant (Platte thistle, Cirsium canescens) in the Nebraska Sand Hills, USA. Dark gray areas represent sand hill, sand sage, and gravelly mixedgrass prairie vegetation, while light gray areas represent all other vegetation types. The ellipse designates sites that were categorized as "central." Sites outside of this area, but within the Sand Hills formation, were designated as "edge." The sites categorized as "disjunct" were those that were located in sand/gravel areas that were not connected with the main body of the Sand Hills. Sites are coded by presence vs. absence of $R$. conicus on C. canescens in 1996-1998: open circles represent sites in which $R$. conicus was never observed, while solid circles represent sites in which R. conicus was present in at least one year. (B) County-level abundance of the exotic, targeted musk thistle, Carduus nutans, across the state, based on 1999 county weed infestation reports of the Nebraska Department of Agriculture. Categories represent the percentage of each county infested by C. nutans at any level (trace-severe). The Sand Hills formation and peripheral sand patches are outlined in black.

Carduus nutans (Frick 1978, Zwölfer and Harris 1984, Gassmann and Louda 2001), and into Nebraska in 1969-1972 (McCarty et al. 1967, McCarty and Lamp 1982). In Nebraska, C. nutans occurs primarily in midand tallgrass prairie grasslands on the richer loam soils, especially in the eastern and south-central portions of the state (Fig. 1B). In the $48640-\mathrm{km}^{2}$ Sand Hills region of Nebraska (Fig. 1A), where C. nutans is rare, if present at all, the predominant thistle is the sparsely distributed native Platte thistle, $C$. canescens; this species is 
restricted to the sand and gravel soils centered on this region of the upper Great Plains (Great Plains Flora Association 1977, 1986). The distribution of the sand and gravel deposits, and the specificity of C. canescens to these soil types, results in a distinctive "mainlandisland" structure to the native plant's habitat, and so to the plant's distribution. The Sand Hills geological formation makes up the central and most extensive "mainland" area of habitat, while a number of sand and gravel outcrops surrounded by richer, loam soils form smaller disjunct habitat "islands" peripheral to the main formation (Fig. 1A).

Rhinocyllus conicus reduces thistle seed production by laying eggs on developing thistle flower heads, into which its larvae then burrow and feed (Zwölfer and Harris 1984, Gassmann and Louda 2001). In 1993, it was found invading two long-term thistle study sites in the Nebraska Sand Hills, where oviposition was first observed on study plants of a nontargeted native species, C. canescens (Louda et al. 1997, Louda 1998). The density of $C$. canescens at these sites has declined significantly subsequent to the $R$. conicus invasion, and densities in long-term demographic plots now average $<5 \%$ of the pre-1993 invasion densities (Louda and Arnett 2000, Louda et al. 2003).

A fundamental issue in assessing the broader threat posed by $R$. conicus to $C$. canescens is whether the nontarget feeding and impact reported is locally restricted or not (Boldt 1997, Louda et al. 1998). To assess this broader threat, and to evaluate the relevance of the intensive data on the $R$. conicus $-C$. canescens interaction at the long-term study sites for the larger scale outcome of this interaction, we quantified the overlap of $R$. conicus distribution with that of $C$. canescens across the center of the plant's biogeographic range, the magnitude of the interaction on this larger scale over three years, and investigated the potential influence of geographic variation in abiotic factors and plant traits on the intensity and spatial pattern of weevil attack on $C$. canescens.

Regional-scale variation in the occurrence and magnitude of $R$. conicus attack on $C$. canescens could reflect a number of underlying factors. These include: largescale variation in important climatic factors, such as regional variation in temperature and precipitation; spatial proximity of this host plant to populations of the targeted exotic thistle, $C$. nutans; availability of $C$. canescens flower head resources; or, some combination of these factors. Based on both the location of initial releases and the availability of the targeted, coevolved host $C$. nutans, which occurs primarily in prairie grasslands on richer, heavier soils that surround the Sand Hills formation and is very rare within it (McCarty 1978; Fig. 1B), we predicted that densities of $R$. conicus on the native $C$. canescens should be highest on the small, disjunct "sand islands," in close proximity to $C$. nutans habitat, and lowest in the center of the Sand Hills formation, farthest from areas infested with the exotic thistle and, thus, potential sources of weevils. Such a pattern of nontarget attack would be consistent with reports of nontarget feeding on native species associated with biocontrol agent "spillover" from the targeted species onto natives in close proximity (Blossey et al. 2001, Rand and Louda 2004, Rand et al. 2005). Spillover of $R$. conicus from exotic $C$. nutans populations has been shown to increase use of associated native thistles in prairies on loamy soils at both local and landscapes scales (Rand and Louda 2004, Rand et al. 2005). Theoretical studies further suggest that such "spillover effects" could be important at larger spatial scales, even when the target and nontarget species do not occur in the same habitat type (Holt and Hochberg 2001), as in our study system.

However, a case might also be made for the opposite pattern. One consistent prediction from current spatial theories, including diffusion, island biogeographic and metapopulation models, is that the host/resource species will be more abundant in larger core areas of habitat and less abundant in peripheral, smaller, or more isolated habitat patches (MacArthur and Wilson 1967, Brown 1984, Hanski and Gilpin 1997, Connor et al. 2000). Since insect herbivore densities often increase with local resource density (Root 1973), this could result in reduced herbivore pressure in isolated or peripheral host plant populations. In fact, such reductions in herbivore abundance and/or impact on host plants as a result of isolation and fragmentation have been documented in previous studies (Kruess and Tscharntke 1994, Steffan-Dewenter et al. 2001). If $R$. conicus responds primarily to spatial variation in the local availability of its newly adopted host, C. canescens, across this region, then this body of theoretical and empirical work leads to the prediction that weevil abundance on $C$. canescens should be greatest in the "mainland" portion of the host plant's range, and lowest on host plants occurring in low densities in the disjunct habitat "islands."

Finally, an understanding of the environmental factors influencing variation in abundance of an exotic insect could be important to predicting its biogeographic spread and impact. Large-scale variation in climatic factors, especially temperature and precipitation, has long been recognized to have an important influence on insect population dynamics and distribution (Andrewartha and Birch 1954, Price 1984, Gilbert and Rowarth 1996). Also, plant growth and flowering effort often respond to variation in temperature and precipitation patterns (see Gurevitch et al. 2003, Russell and Louda 2005). Thus, the direct effects of variation in large-scale abiotic parameters, or the indirect effect of such variation on plant growth and flower head resources, across the plant's range may help explain spatial variation in $R$. conicus occurrence on $C$. canescens at the regional scale. Geoclimatic factors shown to be important predictors of herbivorous-insect pest dynamics across local to regional scales include: degree-day 
accumulations, temperature range, moisture, and soil characteristics (e.g., Harcourt and Guppy 1991, Lerin and Koubati 1997, Schell and Lockwood 1997). For $R$. conicus, laboratory and local-scale field surveys have demonstrated that weevil abundance, mortality, oviposition, and development rate are influenced by temperature, specifically degree-day accumulations, and moisture (Surles et al. 1975, Smith and Kok 1985, 1987), including at our two long-term study sites in Nebraska (Russell and Louda 2005). Thus, we predicted that large-scale variation in these abiotic parameters across the biogeographic range of $C$. canescens could be useful predictors of patterns of $R$. conicus abundance on it, either directly or indirectly via effects on host plant traits, such as plant size and flower head resource availability.

In order to quantify the spatial extent of the threat posed to $C$. canescens by $R$. conicus and to evaluate hypotheses for large-scale spatial patterns of variation in weevil abundance on $C$. canescens, we focused on four specific questions. First, does $R$. conicus occur throughout the distribution of $C$. canescens, or is the reported interaction locally restricted? Second, does $R$. conicus abundance on $C$. canescens vary in relation to plant position within its biogeographic range, i.e., in the main Sand Hills formation vs. in peripheral sand and gravel patches? Third, is the pattern of $R$. conicus abundance on $C$. canescens consistent with a "spillover" model, or conversely, with an island biogeographic model of interaction? Finally, fourth, to what extent can largescale variation in abiotic or biotic factors known to affect insect performance predict variation in $R$. conicus abundance on $C$. canescens (Platte thistle) across the center of its biogeographic range?

\section{Methods \\ Data collection}

The center of the documented distribution and abundance of Cirsium canescens is the $48640-\mathrm{km}^{2}$ Sand Hills formation of Nebraska, the largest continental dune grassland in the western hemisphere (Bleed and Flowerday 1989); peripheral populations occur on sand and gravel outcrops in Nebraska, southern South Dakota, eastern Wyoming as well as eastern and central Colorado (Great Plains Flora Association 1977, 1986; S. M. Louda, personal observation). To quantify the distribution and abundance of $R$. conicus on $C$. canescens, we quantified insects in flower heads of plants sampled across this range in Nebraska in 1996-1998 (Fig. 1A).

Site location involved stratified sampling of sites across the plant's range. In 1996, we divided each county in the Sand Hills into four quadrants and established proposed sampling points on a map by centrality and accessibility within each quadrant. In addition for Cherry County, with about four times the area of the average county in the state, we divided each quadrant again into quarters to establish sampling points. In the field, we sampled the $C$. canescens stand found nearest each proposed point. Additionally, peripheral sand patches, separated from the main formation and surrounded by richer soils, were identified on the Nebraska soils map (Fig. 1A). Sampling sites within these patches were planned to cover their extent, with at least $15 \mathrm{~km}$ between sites; thus, several sites were located within the larger sand patches, while smaller patches were usually represented by one sampling site. All of the sites sampled were in or adjacent to permanent rangeland pastures. Average distance between all sites (mainland, peripheral) was $\sim 30 \mathrm{~km}$. In 1996, plants were sampled at 92 sites. In 1997, these 92 sites were resampled, and 11 additional peripheral sites were found to expand our sample of disjunct populations $(n=103)$. In 1998, the original 92 sites plus the 11 sites added in 1997 were re-sampled, and an additional 5 new disjunct, peripheral sites were found and sampled $(n=108)$. Specifically, the extensive sampling regime steadily increased representation of peripheral populations, the hardest sites to find, as the study progressed.

In each of the three years, five $C$. canescens plants per site were measured and at least $50 \%$ of their flower heads collected. The local populations of this species, the predominant thistle in the Sand Hills, tend to occur in small patches e.g., $10 \times 50 \mathrm{~m}$ per site $(\mathrm{S}$. M. Louda, personal observation). The five plants to be measured for each local population at each site were selected as a stratified sample along a transect through the patch, starting from an arbitrary point; the rule was to measure every other flowering plant encountered, or every third one in denser patches, with the proviso that sampled plants were $>2 \mathrm{~m}$ apart. This stratified sampling regime was designed to allow rapid collection of comparable, unbiased samples across a large number of sites (92-108 each year) across the $>50000 \mathrm{~km}^{2}$ sampled within a short (8-d) period. We sampled as rapidly as possible to maximize the phenological comparability among sampling sites near the end of the flowering season.

For each plant sampled, we measured the stem height (centimeters), counted both the total number of flower heads initiated and the number that had flowered (exerted at least one floret), and then collected flower heads for dissection. The heads collected from each plant each year were: the main terminal flower head, the terminal head on alternating side branches, and the first subsidiary flower head below a branch terminal with a diameter $\geq 15 \mathrm{~mm}$. These heads represent $>50 \%$ of all heads, on average, and the flower heads with the highest probability of setting seed (Louda and Potvin 1995). The data and samples were collected 21-28 June 1996-1998, at the end of both the observed oviposition period for $R$. conicus and the main flowering period for $C$. canescens (Russell and Louda 2004).

In the laboratory, each flower head was measured (diameter, millimeters), weighed, and dissected ( $n=$ 1450, 1270, and 1123 heads, in 1996, 1997, and 1998, respectively). For each head, the number and type of 
insects, as well as the evidence of insect feeding, were recorded. These counts included all adult, pupal, and larval weevils, as well as egg cases and pinhole entry points, and the number of distinctive pupal chambers made by the late-instar weevils. Since many weevils emerged from flower heads before collection, we used the larger of the count of weevils or weevil pupal chambers as the most accurate estimate of the number of successful weevils that developed in the flower head.

In order to determine whether weevil abundance varied in relation to biogeographic position across the range of $C$. canescens in Nebraska, we divided the sampled range into three categories. These included central core vs. edge regions of the "mainland" Sand Hills formation, and the disjunct peripheral sand patches. Sites in the central core area of the Sand Hills were defined as those that were contained within an ellipse centered at the widest point in the length and width of the Sand Hills formation, and adjusted so that central sites were at least $50 \mathrm{~km}$ from extensive areas with a different soil and vegetation type (Fig. 1A). Initial analyses showed that the results did not vary substantially when the central core area was defined in alternative ways, e.g., using a circle rather than an ellipse or estimating distance from a central point. Sites categorized as "edge" were located outside the central core ellipse, but still within the "mainland" Sand Hills formation. Disjunct sites were those in peripheral sand patches that were separated from the main formation by a different soil type. Site locations were mapped in ArcView GIS 3.2 (ESRI 1999). Estimates of exotic $C$. nutans abundance per county also were mapped in ArcView, in order to assess whether proximity to areas varying in level of infestation by the exotic might explain biogeographic patterns of variation in weevil abundance. County-level C. nutans abundance data were extracted from 1999 county weed infestation reports obtained from the Nebraska Department of Agriculture, Noxious Weed Program (unpublished data). The percentage of each county infested by $C$. nutans (number of infested acres/number of acres in county $\times 100)$ at any level (trace to severe) was calculated and incorporated into the GIS map (Fig. 1B). Counties containing sampling sites were categorized as central, edge, or peripheral. Counties that spanned more than one position (e.g., formation center and edge) were placed within the category containing the majority of their sampling locations or area.

To determine whether large-scale spatial variation in $R$. conicus abundance could be predicted by regional variation in abiotic variables, the environmental variables were extracted for each site from a GIS database (Milner et al. 2002). Soil variables, including root zone water-holding capacity and surface organic matter, were obtained from the Nebraska State Soil Geographic (STATSGO) database (Natural Resources Conservation Service 1994). Root zone water-holding capacity is a measure of the available water-holding capacity across an effective rooting depth, which represents the root zone's potential storage in millimeters (Sinclair et al. 1998). Large-scale climate variables examined included regional patterns in: growing degree-days, average temperature, and precipitation. Growing degree-days estimate the total heat units accumulated and available for growth throughout the year. The data [in degrees Fahrenheit, ${ }^{\circ} \mathrm{F}$, where $32^{\circ} \mathrm{F}=0^{\circ} \mathrm{C}$ and each degree Fahrenheit $\approx 0.556$ degree Celsius] were derived from the period 1961-1990, based on the formula [( $T_{\max }-$ $\left.\left.T_{\min }\right) / 2\right]-50^{\circ} \mathrm{F}$, and the grid surface was generated from a terrain regression applied to the U.S. Geological Survey 3 arc-second digital elevations models (Waltman et al. 1998). Average temperature $\left[\left(T_{\max }+T_{\min }\right) / 2\right]$ and precipitation (millimeters) were calculated for each site, based on data from the nearest weather station (High Plains Climate Center, University of Nebraska, Lincoln, Nebraska, USA). We used average temperature over the three-month spring interval during which weevil activity and plant flowering occur (1 April-30 June) for each year 1996-1998. Precipitation data represented the cumulative amount rainfall (centimeters) over this same interval in each year.

\section{Statistical analyses}

Using JMP 4.0.4 (SAS Institute 2001), we calculated site means for stem height (as an estimate of plant stature/size) and total number of flower heads (as an estimate of floral resource availability for R. conicus). To calculate the site means, we averaged over all of the plants with the typical single-stemmed morphology sampled at a given site within a given year. Additionally, for the synthesis represented in the path analysis, we calculated the cumulative means over all plants at each site over all three years. Both annual and cumulative averages are independent estimates since $C$. canescens is monocarpic; individual plants die after flowering and so cannot be re-measured. For the parameters that we measured on a per flower head basis, such as flower head diameter and weevil density, we calculated site means by finding the mean value for each plant and then averaging the plant means for the site, since the plant was the replicate sampling unit for the site. Cumulative means for the overall path analysis were calculated by averaging plant means at each site over all three years. Finally, we examined more directly the potential effects of exotic thistle abundance, estimated at the county level, on $R$. conicus abundance on $C$. canescens. First, we calculated a county-level estimate of weevil density per flower head by averaging plant means for all the plants measured within a given county across the three years of the study. Second, these were analyzed in relation to county-level musk thistle infestation and biogeographic position. Variables were transformed when necessary to normalize distributions and homogenize variances; counts of $R$. conicus and flower heads per plant were power-transformed $\left(x^{0.5}\right)$, and root zone water-holding capacity was $\ln (x)$-transformed. 


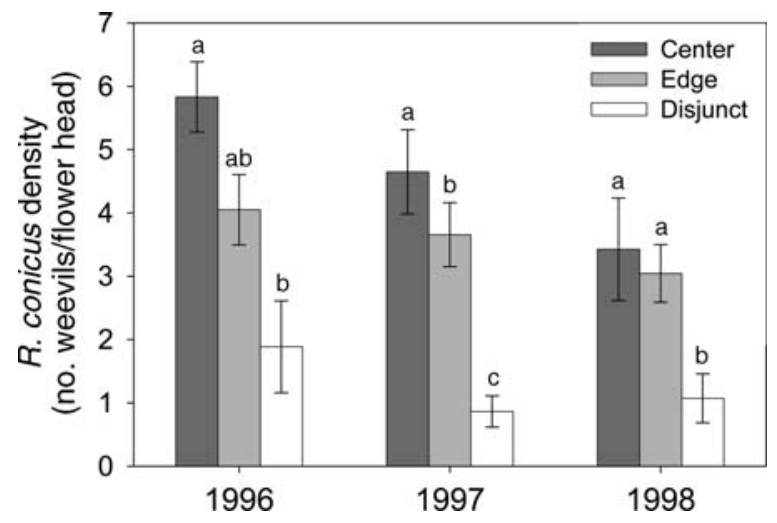

FIG. 2. The density of $R$. conicus within each of the three biogeographic locations in each year. Bars represent untransformed means \pm SE. Sample size (number of sites) varied by location and year: 1996, $n=30,53$, and 10; 1997, $n=30,56$, and $17 ; 1998, n=30,56$, and 23 , in center, edge, and disjunct locations, respectively. Locations with different letters differ significantly with respect to $R$. conicus density $(P<0.05)$, based on post hoc contrasts using least-squares means from regression models.

We used stepwise multiple regression models (with backwards elimination) to examine the potential effects of biogeographic position, as well as those of large-scale variation in soil, climate, and plant variables, on $R$. conicus densities on $C$. canescens across sites in each year. Biogeographic position was a categorical variable, with sites designated as either in the Sand Hills formation central core, formation edge, or disjunct peripheral sand patch. We included root zone waterholding capacity as the soil variable, because it explained more of the variance in $R$. conicus density than did surface organic matter, and because only one soil variable could be included to avoid colinearity. Regional climatic variables included in initial models included: growing degree-days, cumulative precipitation, and average temperature. Potentially biologically relevant first-order interactions between abiotic variables (precipitation by growing degree-days, precipitation by temperature, precipitation by root zone water-holding capacity) were also included in initial models. Finally, the two plant performance variables included in the initial models were stem height (stature) and the number of flower heads per plant (weevil resources). We also ran stepwise regression models to examine the effect of large-scale variation in soils, climate, and biogeographic location on the two plant variables. None of the final models showed colinearity; variance inflation factors (VIFs) were always $<5$ (Montgomery and Peck 1992).

Analysis of variance and covariance were used to more directly test for differences in levels of C. nutans infestation by biogeographic location (Sand Hills core, edge, or disjunct peripheral areas), and to evaluate the relative contribution of variation in $C$. nutans abundance and biogeographic position to explaining patterns of spatial variation in county-level estimates of $R$. conicus densities on $C$. canescens. The infestation level of musk and $R$. conicus density were power-transformed $\left(x^{0.2}\right.$ and $x^{0.5}$, respectively) prior to analysis to meet model assumptions.

Finally, we used path analysis, using structural equation models with LISREL, version 8.51 (Joreskog and Sorbom 2001), to estimate the overall relative contribution of direct and indirect effects of the abiotic and biotic factors hypothesized to affect insect abundance. LISREL uses maximum-likelihood estimation techniques to estimate path coefficients (Johnson et al. 1991). The same variables used in the initial stepwise regression models were included in the LISREL model, transformed as necessary to meet assumptions of normality. To simplify the analysis in the development of hypotheses for further study, we used average values over the three years and treated location (with three levels) as a continuous variable; the latter is standard in structural equation modeling, given the number of categories exceeds two and skewness is $<1$ (Byrne 1998). All of the causal pathways hypothesized to be potentially important were included in the model, with the exception of location effects on plant variables (stem height, head number); location was considered a priori as unlikely to be an important predictor of plant traits independent of the regional variation in soil and climate parameters. We also included paths to test for correlations between exogenous variables that might be interdependent. Exclusion of nonsignificant paths did not improve model fit significantly $\left(P>0.10\right.$ for all $\chi^{2}$ tests; see Mitchell 2001); however, including the path from location to head number marginally increased model fit $(P<0.10)$, and, thus, it was included in the final structural model.

\section{RESUlts}

Geographic overlap of the exotic weevil and the native host plant

Rhinocyllus conicus was present at $93.5 \%$ of all sites (101 of 108) surveyed 1996-1998 (Fig. 1A). The densities of $R$. conicus (mean \pm SE number of weevils/flower head) at the two long-term study sites (Arapaho Prairie Preserve $=3.65 \pm 0.63$; Niobrara Valley Preserve $=$ $3.15 \pm 0.55)$ were close to the middle (median $=3.24$ ) of the distribution and representative of the average density observed across all sites (3.32 \pm 0.23$)$. Mean $R$. conicus density per flower head varied across sites, and ranged from 0 to a maximum of 11.4 weevils per $C$. canescens flower head.

\section{Biogeographic patterns of Rhinocyllus conicus abundance on Cirsium canescens}

We found strong spatial patterns in weevil density on Cirsium canescens as a function of general position within its biogeographic range (Fig. 2). Overall, biogeographic position (central core vs. edge vs. disjunct areas) within and around the Sand Hills formation consistently explained $R$. conicus density (mean number per flower 
TABLE 1. Results of stepwise regression models examining the influence of plant, soil, and regional climate variables as well as biogeographic location (center, edge, or disjunct) on site-level Rhinocyllus conicus density in Cirsium canescens flower heads (mean no. weevils/flower head) in 1996, 1997, and 1998.

\begin{tabular}{|c|c|c|c|c|c|c|c|c|c|}
\hline \multirow[b]{2}{*}{ Source } & \multicolumn{3}{|c|}{1996} & \multicolumn{3}{|c|}{1997} & \multicolumn{3}{|c|}{1998} \\
\hline & Coefficient & $F$ & $P$ & Coefficient & $F$ & $P$ & Coefficient & $F$ & $P$ \\
\hline Stem height & NS & NS & NS & NS & NS & NS & -0.029 & 4.03 & 0.047 \\
\hline Total flower heads & 0.471 & 10.15 & 0.002 & 0.406 & 12.19 & $<0.001$ & 0.709 & 21.36 & $<0.001$ \\
\hline Root zone water-holding capacity & -0.245 & 3.34 & 0.071 & -0.299 & 6.31 & 0.014 & NS & NS & NS \\
\hline Growing degree-days & -0.001 & 7.87 & 0.006 & NS & NS & NS & NS & NS & NS \\
\hline Precipitation & NS & NS & NS & 0.260 & 6.71 & 0.011 & NS & NS & NS \\
\hline Temperature & NS & NS & NS & NS & NS & NS & NS & NS & NS \\
\hline Location & $\sim$ & 4.07 & 0.021 & $\sim$ & 7.03 & 0.001 & $\sim$ & 9.30 & $<0.001$ \\
\hline
\end{tabular}

Notes: Analyses were run using transformed variables for $R$. conicus density, root zone water-holding capacity, and flower head number. Untransformed data were used for all other variables. Tested interactions were never significant and thus are not included in the table (see Methods for details). Whole-model results for 1996 regression, $F_{5,87}=10.31, P<0.001$, adjusted $R^{2}=0.34$; 1997 regression, $F_{5,87}=9.41 ; P<0.001$, adjusted $R^{2}=0.29 ; 1998$ regression, $F_{4,103}=8.75 ; P<0.001$, adjusted $R^{2}=0.23$. For all years, the numerator $\mathrm{df}$ is 1 for all predictor variables except the one categorical variable (Location), which has $2 \mathrm{df}$. For all variables, the denominator df is 87, 97, 103 in 1996, 1997, and 1998, respectively. A tilde $(\sim)$ signifies a categorical variable, and NS signifies nonsignificant factors excluded in stepwise regression (backward elimination) procedures.

head) on $C$. canescens; the effect was statistically significant in all years (Table 1).

Densities of $R$. conicus were more than three times greater in the central core of the distribution than in the disjunct patches, and more than two times greater in the edge region than in the disjunct patches in all three years (Fig. 2). The central core vs. disjunct patch comparison was statistically significant in all three years $(P<0.05)$, and the edge vs. disjunct comparison was also significant except in 1996, using post hoc contrasts of least-squares means from regression models (Fig. 2). Weevil densities also tended to be higher in central core than in the formation edge locations, although this was only statistically significant in 1997 (Fig. 2). The frequency of $R$. conicus occurrence on $C$. canescens (proportion of plants occupied/site) showed the same patterns as weevil density: highest in the central core of the Sand Hills and lowest in the peripheral sand habitat islands. The effect of biogeographic position on frequency of occurrence was highly significant in all three years (ANOVA; 1996, $F_{2,90}=8.71, P<0.001 ; 1997, F_{2,100}=9.27, P<0.001$; $\left.1998, F_{2,106}=4.80, P=0.01\right)$.

Biogeographic position was also a significant predictor of the degree of county-level infestation (percentage of area covered) by the exotic weed, $C$. nutans (one-way ANOVA; $F_{2,31}=11.71, P=0.0002$, adjusted $R^{2}=0.38$ ); densities of the exotic thistle were significantly lower in counties within the central core of the Sand Hills $(<0.0001 \%)$ than in counties containing the edge $(2.16 \% \pm 1.82 \%)$ or the peripheral sand sites $(1.55 \% \pm$ $0.74 \%$ ). ANCOVA revealed that biogeographic position had a strong effect on weevil densities on the native thistle, independent of exotic thistle abundance. When both factors were included in the model, we found a significant effect of biogeographic position $\left(F_{2,30}=4.24\right.$, $P=0.024)$, but not the degree of exotic thistle infestation $\left(F_{1,30}=0.163, P=0.699\right)$ on weevil densities on $C$. canescens.
In summary, we found that $R$. conicus occurred on $C$. canescens throughout its range, and that weevil density and frequency of occurrence were consistently greatest in the center of the native plant's distribution in the Sand Hills, farthest from the surrounding regional areas with higher densities of the weevil's coevolved exotic host plant, C. nutans.

\section{Abiotic and plant variables associated with variation in weevil abundance}

Stepwise regression models that included significant large-scale soil, climate, and/or plant variables, along with biogeographic position, explained a significant proportion of the variance in $R$. conicus density in all years. A greater percentage of the variance was explained in 1996 (34\%) than in 1997 or 1998 (29\% and $23 \%$, respectively; Table 1). Aside from biogeographic position, the only additional consistent predictor of the variation in $R$. conicus density among sites was the mean number of flower heads per plant, which represents the main flower head resource available for $R$. conicus within the Sand Hills formation where $C$. canescens is the predominant thistle species. The density of $R$. conicus increased significantly as the mean number of $C$. canescens flower heads per plant increased in a site in all years (Table 1, Fig. 3).

The effects of other parameters evaluated, including both large-scale variation in abiotic parameters (growing degree-days, temperature, precipitation, root zone water-holding capacity) and a key biotic parameter (stem height) were weak or variable across years (Table 1). For example, densities of $R$. conicus decreased significantly with increasing growing degree-days in 1996, but this factor was not significant (i.e., excluded from models in backwards elimination procedures) in the subsequent two years (Table 1). Growing season precipitation was only significant in explaining $R$. conicus densities in 1997, when densities increased with increased precipitation (Table 1). Densities of $R$. conicus 

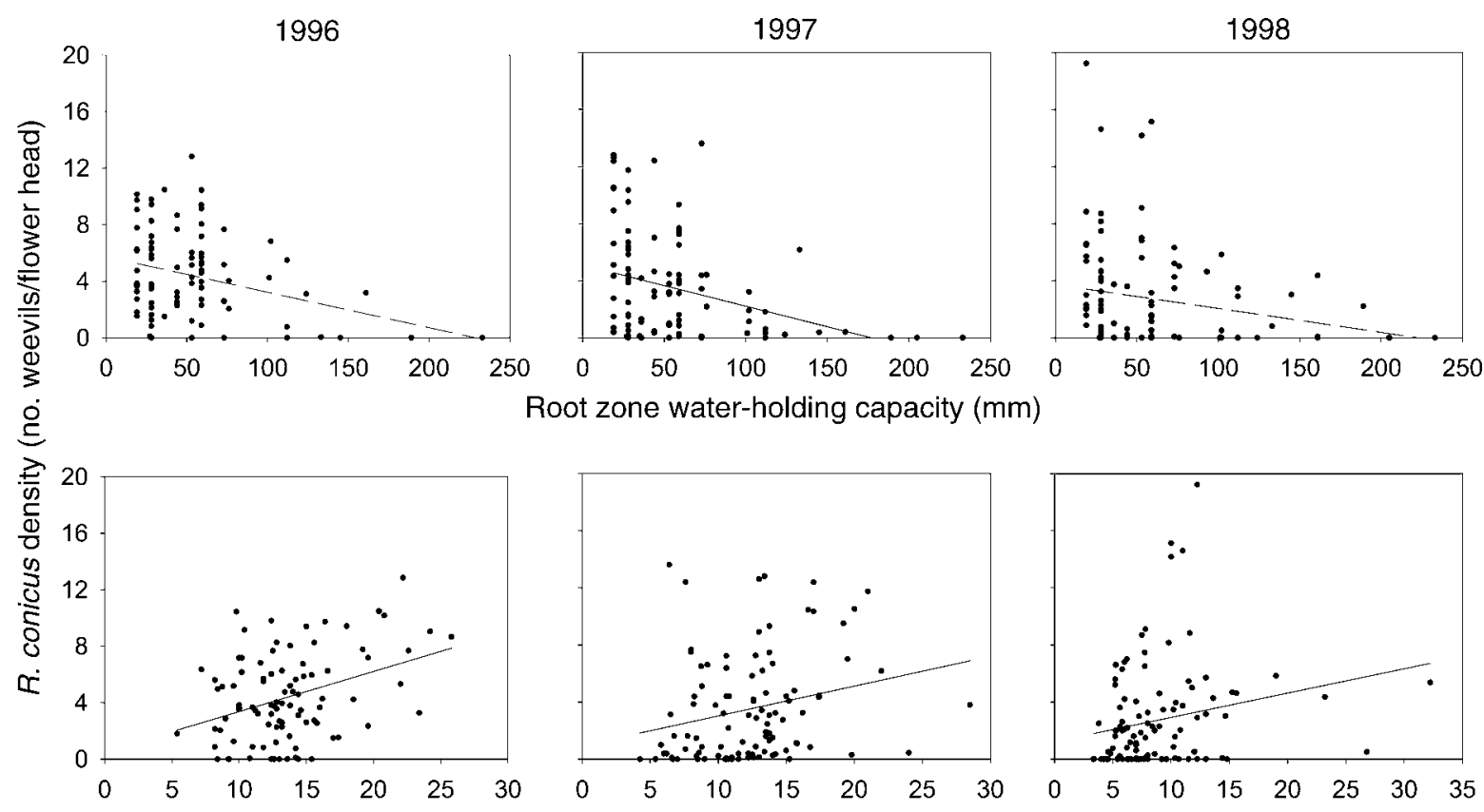

Root zone water-holding capacity $(\mathrm{mm})$
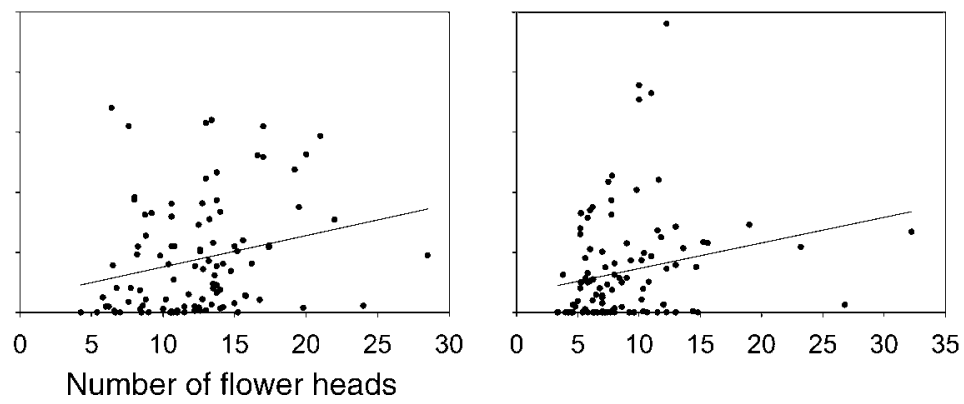

FIG. 3. R. conicus density in relation to regional variation in plant and soil variables in each year. Only variables that had a significant or marginally significant effect on $R$. conicus density in at least two years (based on stepwise multiple regression models) are presented. Each point represents a site mean ( $R$. conicus density, number of flower heads) or site value (root zone water-holding capacity). Untransformed data are presented for all variables. Least-squares regression lines are presented to illustrate trends in the data. Significant relationships are indicated with solid lines, while dashed lines represent insignificant trends.

generally decreased with increased root zone waterholding capacity (Fig. 3). This factor was significant in 1997, marginally significant in 1996, but not significant in 1998 (Table 1). Finally, within growing season, temperature was never a significant predictor of $R$. conicus abundance (i.e., was never retained in stepwise models).

The influences of the abiotic variables on the native plant resource for the weevil, measured as plant stature and total number of flower heads, were similarly weak or highly variable. None of the factors examined, including root zone water-holding capacity, macroclimatic parameters (growing degree-days, temperature, precipitation), or biogeographic location, contributed significantly to explaining the variance in the number of flower heads per plant across sites in either 1996 or 1997 (i.e., all factors were removed in backwards elimination procedures). In 1997, the mean number of flower heads per plant decreased significantly with increases in growing degree-days (coefficient $=-0.0009, F_{1,100}=$ 7.53, $P=0.007)$, but increased with temperature (coefficient $\left.=0.2892, F_{1,100}=10.58, P=0.002\right)$. Overall, however, the significant model $\left(F_{2,100}=5.74, P=0.004\right)$ explained only $8 \%$ of the variation in the number of flower heads per plant across sites (adjusted $R^{2}=0.08$ ). For stem height (plant stature), none of the examined parameters, including large-scale climate and soil variables or biogeographic location, were informative for predicting variation in plant size in either 1997 or
1998. In 1996, stem height increased significantly with increasing degree-days (coefficient $=0.0109, F_{1,90}=$ $11.17, P=0.001)$ and showed a marginally significant decreasing trend with increasing temperature (coefficient $=-1.862, F_{1,90}=3.38, P=0.070$ ). However, once again the overall model explained very little of the overall variance in stem height (adjusted $R^{2}=0.09, F_{2,90}=5.75$, $P=0.005$ ).

In the exploration of hypothesized relationships using path analysis, we found that biogeographic location, total number of $C$. canescens flower heads, and root zone water-holding capacity had strong direct effects on $R$. conicus density on C. canescens (Fig. 4). The standardized parameter values, equivalent to standardized path coefficients, were rescaled to have a variance of 1.0; thus, direct comparisons of the relative strengths of each effect are possible (Johnson et al. 1991). Location had the largest effect, and the negative coefficient indicates that $R$. conicus density decreased from central core to edge to disjunct peripheral locations overall. Next, $R$. conicus densities increased as the number of flower heads of $C$. canescens increased. Root zone water-holding capacity also had an overall direct effect, with densities of $R$. conicus on $C$. canescens decreasing as water-holding capacity increased. Root zone water-holding capacity was positively correlated with location (Fig. 4), increasing from a mean of $3.6 \pm$ $0.11 \mathrm{~mm}$ for sites in central core locations, to $4.4 \pm 0.12$ $\mathrm{mm}$ in disjunct sand patches. Also, growing degree-days 


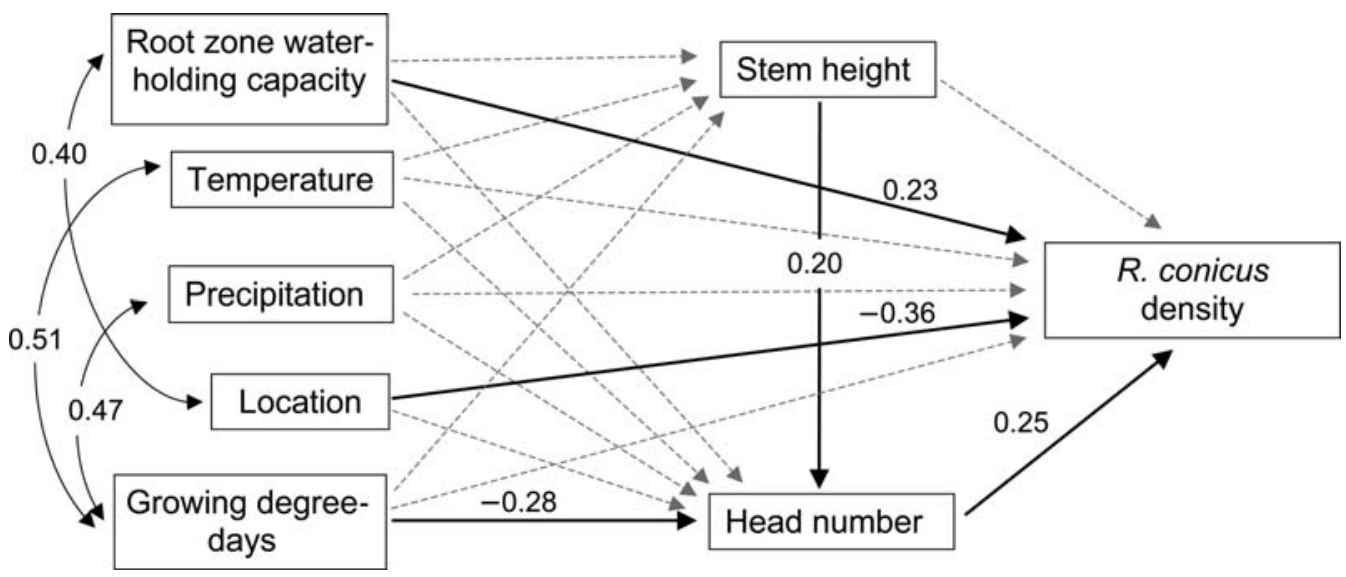

FIG. 4. Structural equation analysis diagram based on maximum-likelihood estimation of path coefficients (LISREL program). All hypothesized paths were included in the model diagram. Significant paths are solid black arrows; nonsignificant paths are dashed gray arrows. Standardized solutions (path coefficients) for each path are presented along each arrow for significant paths. The standardized solutions for the only two significant indirect effects were -0.07 for growing degree-days mediated through head number and 0.05 for stem height mediated through head number.

were positively correlated with growing season precipitation and temperature (Fig. 4).

Potential causal pathways for indirect effects emerged due to significant direct effects of both growing degreedays and stem height on the number of flower heads, which directly influenced $R$. conicus density (Fig. 4). However, the calculated magnitudes of the indirect effects were very small for both growing degree-days (standardized solution $=-0.07$ ) and stem height (standardized solution $=0.05$ ). These overall results are consistent with the regression analyses, but they provide an alternative way of identifying and integrating direct and indirect effects, and they permit a comparison of the relative strengths of the parameters measured in predicting $R$. conicus densities on $C$. canescens across the host plant's distributional range.

\section{Discussion}

\section{Geographic overlap of the exotic weevil with the native host plant}

The data from this study resolve a critical, but controversial issue regarding the spatial extent of the threat posed by $R$. conicus to C. canescens (Boldt 1997, Louda et al. 1997, 1998). The results unambiguously demonstrate that $R$. conicus is abundant throughout the center of the distribution of this adopted native host species. We found that the weevil was broadly distributed across the entire Sand Hills and surrounding region, occurring at $94 \%$ of the sites surveyed, which constitutes the majority of the habitat of $C$. canescens (Great Plains Flora Association 1986). Our results suggest that the negative effect of $R$. conicus on seed production and population dynamics demonstrated with intensive data at two long-term study sites in the Sand Hills (Louda and Arnett 2000, Louda et al. 2003, Rose et al. 2005) is likely a general, widespread phenomenon.
We found no strong latitudinal or longitudinal patterns in the occupancy of sites by $R$. conicus (Fig. 1A), despite the fact that the original release sites of $R$. conicus (1969-1972) were restricted to the southeast and south-central areas of the state (McCarty and Lamp 1982; Fig. 1B). Thus, in the 30-plus years since its release in Nebraska, the weevil has spread and established throughout the state, even in the large central Sand Hills region, which lacks significant populations of its targeted thistle host, Carduus nutans. Given the broad distribution of $R$. conicus across our sampling region, its documented occurrence in states both to the east and west (Louda et al. 1997), its establishment in Canada, as well as eastern and western states, and its broad distribution in Europe (Zwölfer and Harris 1984, Klein and Seitz 1994), it is clear that the range of the weevil far exceeds the relatively restricted range of $C$. canescens in prairie grasslands on sand and gravelly soils of the north-central Great Plains (Great Plains Flora Association 1986). Furthermore, the densities of $R$. conicus at the two sites where it is known to be having a significant negative impact on $C$. canescens populations (Arapaho Prairie Preserve and Niobrara Valley Preserve) were found to be representative of the average densities observed across all sites. Thus, despite previous skepticism (Boldt 1997), the data available now support the inference that the weevil poses a major threat to $C$. canescens populations across a large proportion of its range.

\section{Biogeographic patterns and potential biological mechanisms}

The abundance of the exotic weevil on the native Platte thistle, $C$. canescens, was greatest in the central core of the Sand Hills prairie habitat that forms the main part of the plant's distribution (Fig. 2). In fact, $R$. conicus was two to three times more abundant there than 
in the disjunct sand and gravel sites, which are surrounded by prairie on loamier soils and higher densities of the targeted, coevolved host. The pattern of highest exotic weevil abundance on $C$. canescens in the center of the plant's distribution vs. lowest abundance on plants in the disjunct sites was consistent across all three sampling years, indicating its robustness. The data suggest that the nontarget effects associated with higher densities of $R$. conicus are likely most severe at the center of the distribution of the focal native thistle, while $C$. canescens currently appears to experience a relative refuge from this exotic insect herbivore in the disjunct sand patches.

The observed pattern in insect herbivore abundance is contrary to that expected if spillover effects were driving native plant use by the weevil at the spatial scale examined. The targeted exotic weed, Carduus nutans, is generally restricted to prairie on the loamier soils outside and around the Sand Hills formation (Fig. 1B). The degree of $C$. nutans infestation varied with biogeographic position; it was extremely low in the counties containing the central core of the Sand Hills formation $(<0.0001 \%)$ and much higher in those counties containing the edge $(2.16 \% \pm 1.82 \%)$ and the peripheral sand sites $(1.55 \% \pm 0.74 \%)$. Consequently, if spillover was the main process determining $R$. conicus' use of and abundance on $C$. canescens, then weevil densities should have been lowest in the central core of the Sand Hills, increasing in the edge of the main formation and in the disjunct sand patches which border $C$. nutans habitat. This is exactly the opposite of the pattern that we found. Thus, we conclude that spillover cannot be the driving mechanism underlying the observed pattern of exotic weevil densities on $C$. canescens at the biogeographic scale. This result was quite unexpected, given our previous work demonstrating that such spillover processes increase the use of native thistles by $R$. conicus at both local and landscape scales in prairie on loam soils outside of the Sand Hills formation (Rand and Louda 2004, Rand et al. 2005).

In theory, a number of alternative mechanisms could drive the observed, unexpected large-scale biogeographic pattern in $R$. conicus abundance on $C$. canescens. For instance, one hypothesis is that the distribution of the exotic $C$. nutans does drive weevil use of $C$. canescens, but in opposite direction of that predicted. Lower $R$. conicus use of native $C$. canescens in regions infested by $C$. nutans could result if the weevil preferentially uses its coevolved host if available, such that $C$. nutans acts as a "trap crop." However, this is unlikely for two reasons. First, as already noted, previous studies have shown that native thistles $(C$. undulatum, C. flodmanii), either in close proximity to $C$. nutans patches or in landscapes heavily infested by $C$. nutans, experience higher $R$. conicus egg loads than those isolated from the exotic thistle (Rand and Louda 2004, Rand et al. 2005), in spite of a continued weevil preference for its targeted, coevolved host (Arnett and
Louda 2002). Thus, it is seems highly improbable that the opposite ("trap crop") process is operating at the biogeographic scale. Additionally, we found a strong influence of biogeographic position on $R$. conicus densities on native thistle, independent of the infestation level of $C$. nutans. This finding strongly suggests that factors other than $C$. nutans density are important in driving the observed biogeographic pattern of weevil attack on the $C$. canescens.

Another hypothesis is that the large-scale spatial variation in the use of $C$. canescens by $R$. conicus reflects the availability of other, native thistle resources within the region. However, at least three observations combine to make this hypothesis equally unlikely. First, the three co-occurring native thistles, Cirsium undulatum, $C$. flodmanii and C. ochrocentrum, are even sparser than C. canescens throughout the Sand Hills formation (S. M. Louda, personal observation). Second, all of the cooccurring native thistle species flower later than $C$. canescens (Great Plains Flora Association 1986). Their peak flowering occurs after the $R$. conicus oviposition period, so they are not optimal hosts for the weevil. Third, recent studies have found that variation in $R$. conicus abundance on $C$. canescens in the two main Sand Hills sites, which also contain C. undulatum (the next most common species), was directly related to the availability of $C$. canescens flower heads and not total heads for both species combined (Russell and Louda 2004). Alternately, the weevil's abundance on $C$. undulatum in these sites was inversely related to the availability of $C$. canescens flower heads (Russell and Louda 2005). These observations strongly suggest that in Nebraska, C. canescens is the primary native thistle resource species to which the weevil responds.

In fact, the observed pattern in weevil densities on $C$. canescens resembles that documented in studies of specialized insect herbivores, which have similarly found that herbivore abundances are often highest in large or more connected host plant patches and decrease in small or isolated plant patches (Kruess and Tscharntke 1994, Steffan-Dewenter et al. 2001). This was unexpected in the case of this exotic insect on its new host, especially given the presence of its preferred, coevolved exotic host in habitats surrounding sand prairie. However, a number of observations combine to suggest that, in fact, $R$. conicus abundance on $C$. canescens may well reflect weevil response to spatially structured variation in the local availability of this native host species, which is highly acceptable (Arnett and Louda 2002) and phenologically synchronized (Louda 1998, Russell and Louda 2004).

One of the strongest patterns in biogeography is the tendency for the abundance of an organism to decrease from the center toward the edge of its range (MacArthur 1972, Brown 1995, Frenzel and Brandl 2000). The abundance of $C$. canescens conforms to this pattern, with higher densities generally observed in the central core area of the Sand Hills, which represents the center 
of its geographic range, than in disjunct habitat sand patches at the edges (S. M. Louda, personal observation). In this study, for example, we found that the time required to locate sufficient $C$. canescens plants to sample in the disjunct sand and gravel outcrops near planned sampling points was much greater than in the central region of the Sand Hills. Since insect herbivore densities often increase with local resource density (Root 1973), it is likely that reduced $R$. conicus densities on $C$. canescens in disjunct compared to central core areas reflect the reduced $C$. canescens densities and flower head resources within these peripheral habitats. The positive relationship between the total number of flower heads per plant, one of the main factors influencing the oviposition resource for $R$. conicus in our analysis, and $R$. conicus densities (Fig. 3), reinforces the finding from previous studies (Russell and Louda 2004) that resource availability is an important parameter underlying variation in weevil abundance. The path analysis further supports the general inference of the importance of both location within the regional distribution of, and total flower head resources on, this newly adopted, phenologically synchronized native thistle (Fig. 4). Overall, the path analysis suggests that direct, rather than indirect, processes predominate in determining variation in $R$. conicus density on $C$. canescens across the heart of the plant's range.

We conclude that the most likely explanation for the observed pattern of high weevil densities in the center of the regional distribution of $C$. canescens, and lower densities on $C$. canescens in peripheral disjunct habitat patches, is that $R$. conicus use of $C$. canescens is related to local densities of this native host plant, and local density varies in relation to biogeographic position. A detailed evaluation of this hypothesis presents an interesting avenue for further study.

\section{Lack of large-scale climate effects on the regional-scale abundance of $\mathrm{R}$. conicus}

Previous studies have demonstrated that temperature and degree-day accumulations can have an important influence on $R$. conicus oviposition, larval development, as well as egg and larval mortality (Surles and Kok 1975, Smith and Kok 1985, 1987), as is often observed for herbivorous insects. Specifically, laboratory studies established an apparent threshold for oogenesis $\left(17^{\circ} \mathrm{C}\right)$ and oviposition $\left(15^{\circ} \mathrm{C}\right)$, with no significant differences in number of eggs per female from $19.5^{\circ} \mathrm{C}$ to $36^{\circ} \mathrm{C}$, and demonstrated a deleterious effect of increased temperature (degree-days over $17^{\circ} \mathrm{C}$ ) on oviposition by $R$. conicus (Smith and Kok 1987). However, in field cages, temperature had no effect on mean fecundity per female weevil (Smith and Kok 1987). Larval development started with a hatching threshold of $11^{\circ} \mathrm{C}$, with maximum rates of development between $27^{\circ} \mathrm{C}$ and $36^{\circ} \mathrm{C}$, and maximum mortality observed at or above the temperature for maximum developmental rate $\left(36^{\circ} \mathrm{C}\right)$ in laboratory studies (Smith and Kok 1985).
Across the Sand Hills region, average temperatures during the spring-early summer oviposition and development period of $R$. conicus ranged from $7.9^{\circ} \mathrm{C}$ to $17.2^{\circ} \mathrm{C}$ across sites. Given that the observed temperature range spans the critical thresholds for oviposition, egg hatch, and larval development, and that it is well below the high temperatures found to be detrimental, we expected a strong positive relationship between mean temperature or degree-day accumulation and $R$. conicus abundance on $C$. canescens. However, on the regional scale across the distribution of $C$. canescens in the Nebraska Sand Hills, $R$. conicus density was unrelated to macroclimatic variation in temperature within its activity period, and only weakly related to long-term averages in growing degrees days, which only had a significant effect in one year of the study (Table 1).

The discrepancy between the smaller scale laboratory and field studies and our results could occur if $R$. conicus responds primarily to variation in microclimatic factors, impossible to measure at the scale of our study, as opposed to broader scale variation in macroclimate. Alternately, climatic influences may be complex and influential in ways not examined in our analysis. For example, at the local scale within the two long-term Sand Hills study areas, Russell and Louda (2005) found that no single climatic parameter was significant in predicting temporal variation in $R$. conicus abundance; prediction required a combination of temperature accumulation (growing degree-days) in both winter and early spring preceding the growing season, days since last hard freeze, and precipitation in both the spring and previous summer. In any case, it is clear from the present study that large-scale variation in temperature is not a consistent or straightforward predictor of spatial variation in $R$. conicus numbers on $C$. canescens across the plant's range.

Precipitation also has the potential to influence $R$. conicus dynamics. For example, Surles et al. (1975) found that $36 \%$ of $R$. conicus eggs laid at exposed grassland field sites, similar to those in this study, were dislodged by rain and wind. This suggests that high levels of spring precipitation could negatively influence $R$. conicus abundance by increasing egg mortality. In contrast, Russell and Louda (2005) found that weevil numbers increased with good conditions for plant growth, and specifically increases in within-year spring precipitation along with previous summer precipitation and pre-season temperatures (Russell and Louda 2005). Thus, previous work suggested that precipitation might have negative direct effects on weevil densities via increased egg mortality, while exerting a positive indirect effect through increased growth and subsequent flowering by host plants. In this study, we found that withinseason precipitation was an inconsistent predictor of $R$. conicus numbers across the biogeographic scale (Table 1). In only one year (1997) was there a significant positive relationship between precipitation and weevil densities across the region consistent with the findings of 
Russell and Louda (2005), although the effect was not mediated through host plant traits in this case. In contrast, we never observed the negative relationship expected if increased precipitation increased $R$. conicus egg mortality.

Root zone water-holding capacity was the strongest abiotic predictor of weevil abundances; $R$. conicus abundances were significantly negatively related to root zone water-holding capacity in 1997, with a similar trend in 1996 (Table 1). Since sites with increased root zone water-holding capacity likely have higher soil moisture on average than sandier soils at sites with lower root zone water-holding capacity, we expected a positive relationship, if any; increased soil moisture should positively influence plant growth and reproductive effort and, thus, potentially growth and survival of $R$. conicus. The observed inverse relationship between soil waterholding capacity and $R$. conicus density contradicts this expectation. An alternative hypothesis to explain the observed relationship is that overwinter and early-spring success of $R$. conicus at the soil-litter interface is negatively affected by high soil moisture levels.

In general, we found that large-scale variation in the within-season climatic variables examined were generally weak predictors of the biogeographic spatial patterns in $R$. conicus densities on the native thistle. Neither mean temperature nor cumulative precipitation each year measured over the three-month period of $R$. conicus oviposition and development, nor the long-term (20 year) averages for seasonal growing degree-days, were consistent predictors of $R$. conicus abundance on $C$. canescens over the three years of this study. This result held despite the fact that weevil densities were highly variable across sites, ranging from means of 0 to 11.4 weevils developing per flower head. Regional variation in growing season climate variables generally were also weak predictors of large-scale spatial variation in plant size and reproductive effort (Fig. 4). Thus, although $R$. conicus numbers across the region may be influenced by patterns in soil moisture, we conclude that the abundance and distribution of $R$. conicus across the sand prairie region of the state cannot be explained by consistent large-scale patterns of variation in growing season temperature or precipitation.

\section{Conclusion}

Our results clearly demonstrate that $R$. conicus is widely distributed and abundant on $C$. canescens across the heart of this native plant's distributional range. Given the evidence that $R$. conicus feeding has a significant negative effect on plant performance and, specifically, on seed reproduction of this relatively sparse, seed-limited species, the spatial scale of the threat posed is clear. Within-growing-season variation in macroclimatic factors across the region did not provide any consistent, reliable predictors of the level of occurrence and density of this exotic biocontrol insect on its newly adopted native host plant. In contrast, plant location within the region and C. canescens flower head resource availability strongly influenced weevil abundance on this new host plant. The biogeographic pattern of weevil abundance indicates that, unexpectedly, the newly adopted native host plant is most at risk in the center of its distribution. The implication for conservation is that persistence of this sparse native plant species, in the face of the threat posed by the invasive weevil, likely depends on the integrity and persistence of its disjunct, peripheral populations. These results underscore the value of large-scale studies in quantifying the magnitude and pattern of the threat posed by invasive exotic species to native species and providing quantitative information that is critical to developing strategies for management of such threats. Such data can be used to single out high-risk areas for weevil control efforts, while lower risk areas in peripheral habitats may be identified as having high conservation value and managed for protection and persistence of impacted natives such as $C$. canescens.

The broader implication of our results is that host plant spatial position within islands of natural habitat can be important in determining patterns of exotic insect abundance and potential impact on the native plants. Further, smaller, disjunct populations, the opposite of the "hot spots" often of conservation concern, are potentially critical refuges for native plants threatened by widespread invasive exotic insect herbivores. Protection of populations in such habitats may be crucial to the persistence of sparse native plant species subject to exotic natural enemy impacts.

\section{ACKNOWLEDGMENTS}

We thank the many students, colleagues, friends, and family members who contributed to this project, including Rob Bevill, Amy Hines, Lynn Stanforth, and Steve Trevis in the field and Chad Andersen, Nate Brandt, Kayla Christensen, Lizz Hudnell, Abby Rogers Kula, Sara McLaughlin, and Jeanette Zimmer in the laboratory. S. M. Louda additionally thanks Rod Otley and the late Svata Ann Louda for logistical support, input, and/or invaluable encouragement. Patti Dappen, Maribeth Milner, and David Mortensen provided invaluable GIS support and advice, as well as regional climate and soils data. Mitch Coffin, Nebraska Department of Agriculture, helped us obtain the statewide county weed reports for musk thistle. John Randall of The Nature Conservancy and two anonymous reviewers provided insightful comments on the manuscript. Support for the research was provided by a D. H. Smith Conservation Research Fellowship to T. A. Rand, as well as a University of Nebraska Grant-in-Aid, Katherine Ordway and Rodney Johnson Stewardship Funded Grant from The Nature Conservancy, and National Science Foundation grant (DEB9616210) to S. M. Louda. This is publication number DHS200604 of the David H. Smith Conservation Research Fellowship Program.

\section{Literature Cited}

Andrewartha, H. G., and L. C. Birch. 1954. The distribution and abundance of animals. University of Chicago Press, Chicago, Illinois, USA.

Arnett, A. E., and S. M. Louda. 2002. Re-test of Rhinocyllus conicus host specificity, and the prediction of ecological risk in biological control. Biological Conservation 106:251-257. 
Bleed, A., and C. Flowerday. 1989. An atlas of the Sand Hills. Resource Atlas Number 5. University of Nebraska, Institute of Agriculture and Natural Resources, Lincoln, Nebraska, USA.

Blossey, B., R. Casagrande, L. Tewksbury, D. A. Landis, R. N. Wiedenmann, and D. R. Ellis. 2001. Nontarget feeding of leaf-beetles introduced to control purple loosestrife (Lythrum salicaria L.). Natural Areas Journal 21:368-377.

Boldt, P. E. 1997. Response of a Rhinocyllus researcher. Biocontrol News and Information 18:100N.

Brown, J. H. 1984. On the relationship between abundance and distribution of species. American Naturalist 124:255-279.

Brown, J. H. 1995. Macroecology. University of Chicago Press, Chicago, Illinois, USA.

Byrne, B. M. 1998. Structural equation modeling with LISREL, PRELIS, and SIMPLIS: Basic concepts, applications and programming. Lawrence Erlbaum Associates, Mahwah, New Jersey, USA.

Connor, E. L., A. C. Courtney, and J. M. Yoder. 2000. Individuals-area relationships: the relationship between animal population density and area. Ecology 81:734-748.

Debach, P., and D. Rosen. 1991. Biological control by natural enemies. Second edition. Cambridge University Press, Cambridge, UK.

ESRI. 1999. ArcView GIS 3.2. Environmental Systems Research Institute, Redlands, California, USA.

Ewel, J. J., et al. 1999. Deliberate introductions of species: research needs. BioScience 49:619-630.

Frenzel, M., and R. Brandl. 2000. Phytophagous insect assemblages and the regional species pool: pattern and asymmetries. Global Ecology and Biogeography 9:293-303.

Frick, K. E. 1978. Biological control of thistles in the genus Carduus in the United States: a progress report. Science and Education Administration, USDA, Stoneville, Mississippi, USA.

Gassmann, A., and S. M. Louda. 2001. Rhinocyllus conicus: initial evaluation and subsequent ecological impacts in North America. Pages 147-183 in P. C. Quimby, editor. Evaluating indirect ecological effects of biological control. CABI Publishing, Wallingford, UK.

Gilbert, N., and D. A. Rowarth. 1996. Insects and temperature: a general theory. Canadian Entomologist 128:1-13.

Great Plains Flora Association. 1977. Atlas of the flora of the Great Plains. Iowa State University Press, Ames, Iowa, USA.

Great Plains Flora Association. 1986. Flora of the Great Plains. University Press of Kansas, Lawrence, Kansas, USA.

Gurevitch, J., S. M. Scheiner, and G. A. Fox. 2003. The ecology of plants. Sinauer Associates, Sunderland, Massachusetts, USA.

Hanski, I. A., and M. E. Gilpin. 1997. Metapopulation biology. Ecology, genetics and evolution. Academic Press, San Diego, California, USA.

Harcourt, D. G., and J. C. Guppy. 1991. Numerical-analyses of an outbreak of the alfalfa weevil (Coleoptera, Curculionidae) in Eastern Ontario. Environmental Entomology 20:217-223.

Higgins, S. I., and D. M. Richardson. 1996. A review of models of alien plant spread. Ecological Modelling 87:249-265.

Hoddle, M. S. 2004. Restoring balance: using exotics to control invasive exotics. Conservation Biology 18:38-49.

Holt, R. D., and M. E. Hochberg. 2001. Indirect interactions, community modules and biological control: a theoretical perspective. Pages 13-37 in P. C. Quimby, editor. Evaluating indirect ecological effects of biological control. CABI Publishing, Wallingford, UK.

Howarth, F. G. 1991. Environmental impacts of classical biological control. Annual Review of Entomology 36:485509.

Johnson, M. L., D. G. Huggins, and F. DeNoyelles, Jr. 1991. Ecosystem modeling with Lisrel: A new approach for measuring direct and indirect effects. Ecological Applications 1:383-398.
Joreskog, K., and D. Sorbom. 2001. LISREL. Version 8.51. Scientific International Software, Lincolnwood, Illinois, USA.

Klein, M., and A. Seitz. 1994. Geographic differentiation between populations of Rhinocyllus conicus Froelich (Coleoptera: Curculionidae): concordance of allozyme and morphometric analysis. Zoological Journal of the Linnean Society 110:181-191.

Kruess, A., and T. Tscharntke. 1994. Habitat fragmentation, species loss, and biological control. Science 264:1581-1584.

Lerin, J., and K. Koubati. 1997. Modelling winter oilseed rape plant infestation by Baris coerulescens (Coleoptera: Curculionidae). Environmental Entomology 26:1031-1039.

Louda, S. M. 1998. Population growth of Rhinocyllus conicus (Coleoptera: Curculionidae) on two species of native thistles in prairie. Environmental Entomology 27:834-841.

Louda, S. M., and A. E. Arnett. 2000. Predicting non-target ecological effects of biological control agents: Evidence from Rhinocyllus conicus. Pages 551-567 in N. R. Spencer, editor. Proceedings of the 10th International Symposium on the Biological Control of Weeds. Montana State University, Bozeman, Montana, USA.

Louda, S. M., A. E. Arnett, T. A. Rand, and F. L. Russell. 2003. Invasiveness of some biological control insects and adequacy of their ecological risk assessment and regulation. Conservation Biology 17:73-82.

Louda, S. M., D. Kendall, J. Connor, and D. Simberloff. 1997. Ecological effects of an insect introduced for the biological control of weeds. Science 277:1088-1090.

Louda, S. M., and M. A. Potvin. 1995. Effect of inflorescencefeeding insects in the demography and lifetime fitness of a native plant. Ecology 76:229-245.

Louda, S. M., D. Simberloff, G. Boettner, J. Connor, D. Kendall, and A. E. Arnett. 1998. Insights from data on the nontarget effects of the flowerhead weevil. Biocontrol News and Information 26:70N-71N.

Louda, S. M., and P. Stiling. 2004. The double-edged sword of biological control in conservation and restoration. Conservation Biology 18:50-53.

MacArthur, R. H. 1972. Geographical ecology: patterns in the distribution of species. Harper and Row, New York, New York, USA.

MacArthur, R. H., and E. O. Wilson. 1967. The theory of island biogeography. Princeton University Press, Princeton, New Jersey, USA.

Malecki, R., and B. Blossey. 1994. Insect biological weed control: An important and underutilized management tool for maintaining native plant communities threatened by exotic plant introductions. Pages 400-404 in Transactions, 59th North American Wildlife and Natural Resource Conference (1994). Wildlife Management Institute, Washington, D.C., USA.

McCarty, M. K. 1978. The genus Carduus in the United States. Pages $7-10$ in K. E. Frick, editor. Biological control of thistles in the genus Carduus in the United States. Progress Report, USDA-SEA, Stoneville, Mississippi, USA.

McCarty, M. K., and W. O. Lamp. 1982. Effect of a weevil, Rhinocyllus conicus, on Musk Thistle (Carduus thoermeri) seed production. Weed Science 30:136-140.

McCarty, M. K., C. J. Scifres, and L. R. Robinson. 1967. A descriptive guide for major Nebraska thistles. University of Nebraska, College of Agriculture, Lincoln, Nebraska, USA.

Milner, M., D. A. Mortensen, K. G. Cassman, and W. J. Waltman. 2002. Geospatial applications for Nebraska agriculture. CD 6. University of Nebraska Cooperative Extension. University of Nebraska, Lincoln, Nebraska, USA.

Mitchell, R. J. 2001. Path analysis: pollination. Pages 217-234 in J. Gurevitch, editor. Design and analysis of ecological experiments. Oxford University Press, Oxford, UK. 
Montgomery, D. C., and E. A. Peck. 1992. Introduction to linear regression analysis. John Wiley and Sons, New York, New York, USA.

Natural Resources Conservation Service. 1994. State soil geographic (STATSGO) data base for Nebraska. USDA, Natural Resources Conservation Service, Fort Worth, Texas, USA. 〈http://www.ncgc.nrcs.usda.gov/products/datasets/ statsgo/ $\rangle$

Pimentel, D., L. Lach, R. Zuniga, and D. Morrison. 2000. Environmental and economic costs of nonindigenous species in the United States. BioScience 50:53-64.

Price, P. W. 1984. Insect ecology. Second edition. Wiley Interscience, New York, New York, USA.

Rand, T. A., and S. M. Louda. 2004. Exotic weed invasion increases the susceptibility of native plants to attack by a biocontrol herbivore. Ecology 85:1548-1554.

Rand, T. A., F. L. Russell, and S. M. Louda. 2005. Local vs. landscape scale indirect effects of an invasive weed on native plants. Weed Technology 18:1250-1254.

Root, R. B. 1973. Organization of a plant-arthropod association in simple and diverse habitats: the fauna of collards Brassica oleraceae. Ecological Monographs 43:95-124.

Rose, K. E., S. M. Louda, and M. Rees. 2005. Demographic and evolutionary impacts of native and invasive insect herbivores on Cirsium canescens. Ecology 86:453-465.

Russell, F. L., and S. M. Louda. 2004. Phenological synchrony affects interaction strength of an exotic weevil with the Platte thistle, a native host plant. Oecologia 139:525-534.

Russell, F. L., and S. M. Louda. 2005. Indirect interaction between two native thistles mediated by an invasive exotic floral herbivore. Oecologia 146:373-384.

SAS Institute. 2001. JMP version 4.0.4. SAS Institute, Cary, North Carolina, USA.

Schell, S. P., and J. A. Lockwood. 1997. Spatial analysis of ecological factors related to rangeland grasshopper (Orthoptera: Acrididae) outbreaks in Wyoming. Environmental Entomology 26:1343-1353.

Sinclair, H. R., S. W. Waltman, W. J. Waltman, M. D. Svoboda, and D. A. Mortensen. 1998. Root zone available water-holding capacity of Nebraska landscapes. Map Series Number 98-0116, Department of Agronomy, Institute of Agriculture and Natural Resources, University of Nebraska, Lincoln, Nebraska, USA.

Smith, L. M., and L. T. Kok. 1985. Influence of temperature on the development and mortality of immature Rhinocyllus conicus (Coleoptera: Curculionidae). Environmental Entomology 14:629-633.

Smith, L. M., II, and L. T. Kok. 1987. Influence of temperature on oviposition, quiescence, and mortality of Rhinocyllus conicus (Coleoptera: Curculionidae). Environmental Entomology 16:971-974.

Steffan-Dewenter, I., U. Munzenberg, and T. Tscharntke. 2001. Pollination, seed set and seed predation on a landscape scale. Proceedings of the Royal Society of London, Series B 268: $1685-1690$.

Surles, W. W., and L. T. Kok. 1975. Sequential releases of Rhinocyllus conicus Fröelich (Coleoptera: Curculionidae) for the biocontrol of Carduus thistles. Journal of the New York Entomological Society 83:250.

Surles, W. W., R. L. Pienkowski, and L. T. Kok. 1975. Mortality of the immature stages of Rhinocyllus conicus, a thistle head weevil, in Virginia. Environmental Entomology 4:371-372.

Van Driesche, R. G., and T. S. Bellows. 1996. Biological Control. Chapman and Hall, New York, New York, USA.

Vitousek, P. M., C. M. D'Antonio, L. L. Loope, and R. Westbrooks. 1996. Biological invasions as global environmental change. American Scientist 84:468-478.

Waltman, W. J., M. D. Svoboda, and D. A. Mortensen. 1998. Growing degree-days across Nebraska landscapes. Map Series Number 98-0121, Department of Agronomy and Horticulture, Institute of Agriculture and Natural Resources, University of Nebraska, Lincoln, Nebraska, USA.

Zwölfer, H., and P. Harris. 1984. Biology and host specificity of Rhinocyllus conicus (Froel.) (Col., Curculionidae), a successful agent for biocontrol of the thistle, Carduus nutans L. Zeitschrift der Angewandte Entomologie 97:36-62. 